\title{
Erratum to: Molecular analysis of transgenic melon plants showing virus resistance conferred by direct repeat of movement gene of Cucumber green mottle mosaic virus
}

Emran Md. Ali • Yutaka Tabei · Kappei Kobayashi •

Naoto Yamaoka $\cdot$ Masamichi Nishiguchi

Published online: 9 June 2012

(C) Springer-Verlag 2012

\section{Erratum to: Plant Cell Rep}

DOI 10.1007/s00299-012-1237-9

Unfortunately, the first and last name of the first author has been inverted in the original version. The correct name is Emran Md. Ali.

The online version of the original article can be found under doi:10.1007/s00299-012-1237-9.

E. Md. Ali · K. Kobayashi · N. Yamaoka · M. Nishiguchi ( $₫)$

Faculty of Agriculture, Ehime University, 3-5-7 Tarumi,

Matsuyama 790-8566, Japan

e-mail: mnishigu@agr.ehime-u.ac.jp 